\title{
Quantitative Analysis of Specific mRNA Transcripts Using a Competitive PCR Assay with Electrochemiluminescent Detection
}

\author{
Jeffrey A. Heroux and Ann Marie Szczepanik
}

\begin{abstract}
Neuroscience Product Group Unit, Hoechst-Roussel Pharmaceuticals, Inc., Somerville, New Jersey 08876
\end{abstract}

\begin{abstract}
Reverse transcriptase-polymerase chain reaction ( $R T-P C R$ ) has been widely utilized for both the qualitative and quantitative assessment of the levels of specific mRNA transcripts in living systems. Quantitation of specific transcripts has often proved to be problematic because of the difficulty associated with relating the PCR-amplifled product to the starting CDNA representing the mRNA of interest. We have overcome these difficulties and have developed a competitive PCR assay employing the property of electrochemiluminescence for the detection of PCR products. This assay possesses the dual advantage of being both nonradioactive and highly sensitive.
\end{abstract}

he coupling of the reverse transcription of mRNA with the amplification of discrete DNA sequences via PCR (RTPCR) has allowed for the detection and evaluation of low-abundance RNAs expressed in a variety of biological systems. ${ }^{(1,2)}$ RT-PCR has exceeded the limit of sensitivity of all previously described techniques such as Northern blotting, ribonuclease protection, and in situ hybridization by virtue of its ability to amplify a nucleotide sequence of interest in an exponential fashion using gene-specific primers. Despite the relatively high degree of specificity and sensitivity of RT-PCR, several limitations exist when utilizing this technique for quantitative analysis. This is primarily the case for two reasons: (1) small differences in the amplification efficiency between two in- dividual PCR reactions can lead to significant differences in product yield, thus confounding the interpretation of comparative, quantitative measurements between multiple samples; and (2) there is often a nonexponential accumulation of PCR product, commonly referred to as the "plateau effect," that typically occurs during the later cycles of PCR and is dependent on the starting template concentration. As a result of these events, the amount of PCR product cannot reliably be related to the starting concentration of target DNA and quantitative analysis becomes impossible unless one determines PCR product yield over several cycles or template concentrations. These limitations have been overcome in large measure by the recent development of competitive PCR. ${ }^{(3,4)}$ In competitive PCR, a target sequence is coamplified in the presence of a competitor molecule that contains primer annealing sites identical to that of the target molecule. However, the competitor molecule differs in some other property, such as size or the presence or absence of a unique restriction enzyme site, so as to allow it to be distinguished from the amplified target during the analysis of the PCR products. Because the ratio of target to competitor product is unaffected by the amplification efficiency during PCR, one is able to determine precisely the starting target template concentration by coamplifying varying amounts of competitor in the presence of a fixed concentration of target sequence and a limiting concentration of primers. We report here on the development of a competitive PCR assay that employs electrochemiluminescence (ELCL) de- tection of both PCR target and competitor molecules following coamplification of their respective DNA templates. This assay offers the high sensitivity of ELCL detection of PCR product coupled with the ability to distinguish product molecules by way of a unique restriction site contained within the competitor template. These properties allow for the quantitative detection of low amounts of target DNA template as well as the use of small sample volumes ( $1 \mu$ l or less) for PCR product analysis.

\section{MATERIALS AND METHODS}

\section{Generation of Competitor Molecules}

As illustrated in Figure 1 competitor molecules were synthesized using a modification of a method described previously. ${ }^{(5)}$ In brief, gel-purified target DNA was amplified for 30 cycles using the original forward primer and a modified reverse primer consisting of an 18-base sequence corresponding to the nucleotide sequence immediately $3^{\prime}$ to the original reverse primer sequence, as well as a unique restriction site $(\mathrm{XbaI}$ and a 4-bp "stuffer") and original reverse primer sequences. The purpose of the stuffer sequence was to allow for easier resolution of the target and uncut competitor during gel electrophoresis. The resultant PCR product was gel purified and resuspended in $1 \times$ TE buffer containing $1 \%$ linear acrylamide carrier (Seprasol; Integrated Separations Systems, Inc.).

\section{RT-PCR}

Total RNA was isolated from rat spleen or 


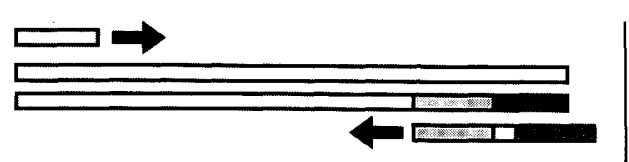

PCR Amplification

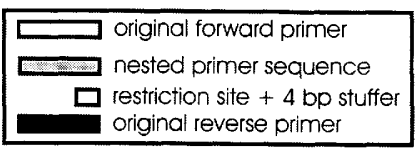

FIGURE 1 Schematic depiction of the PCR generation of IL-1 $\beta$ competitor molecules. The sequence of the restriction site (underlined) and the stuffer sequence was TCTAGACGAA; the sequence of the nested primer sequence was GTGGGTGTGCCGTCTTTC. The size of the PCR-amplified competitor molecule was $282 \mathrm{bp}$.

brain cortical tissue using Trizol reagent (GIBCO-BRL) according to the manufacturer's instructions, reconstituted in 50 $\mu l$ of DEPC water, and stored at $-80^{\circ} \mathrm{C}$ until use. For RT reactions $(20 \mu l$ total volume), $10 \mu$ l of total RNA was mixed with $1 \mu \mathrm{l}$ of oligo(dT) $(0.5 \mu \mathrm{g} / \mu \mathrm{l})$, heated for $10 \mathrm{~min}$ at $70^{\circ} \mathrm{C}$, and chilled on ice. After a brief spin to collect the contents of the tube, $4 \mu \mathrm{l}$ of $5 \times$ buffer $[94 \mathrm{~mm}$ Tris- $\mathrm{HCl}$ at $\mathrm{pH} 6.9,453 \mathrm{~mm} \mathrm{KCl}, 23 \mathrm{~mm}$ $\mathrm{MgCl}_{2}, 750 \mu \mathrm{M} \beta-\mathrm{NAD}, 50 \mathrm{mM}\left(\mathrm{NH}_{4}\right)_{2}$ $\left.\mathrm{SO}_{4}\right)$ ], $2 \mu \mathrm{l}$ of $0.1 \mathrm{M}$ dithiothreitol, $1 \mu \mathrm{l}$ of $10 \mathrm{~mm}$ dNTP stock, $0.5 \mu \mathrm{l}$ of human placental RNA inhibitor, and $1 \mu \mathrm{l}$ of Superscript RT (GIBCO-BRL) were added. The reaction was incubated at $37^{\circ} \mathrm{C}$ for $1 \mathrm{hr}$, inactivated for $10 \mathrm{~min}$ in a boiling water bath, and stored at $-20^{\circ} \mathrm{C}$ until use, at which time the spleen and cortical cDNA samples were diluted 200- and 4-fold, respectively. Typically, $1 \mu \mathrm{l}$ of cDNA was used for each 50- $\mu$ l PCR reaction. Target sequences were amplified using a forward and reverse primer pair that was labeled on the $5^{\prime}$ end with biotin and TBR [Tris (2,2'-bipyridine) ruthenium (II) chelate; Applied Biosystems], respectively. The sequence of the forward primer was Biotin-GAAGCTGTGGCAGCTACCTATGTCT, whereas the sequence of the reverse primer was TBR-AGCTCATGGAGAATACCACT. The size of the target sequence amplified with this primer pair was $272 \mathrm{bp}$. PCR reactions were carried out in $200-\mu l$ thin-walled tubes (Applied Biosystems) in a final volume of $50 \mu \mathrm{l}$, and consisted of $1 \times$ PCR buffer II (50 mM KCl, $10 \mathrm{~mm}$ Tris- $\mathrm{HCl}$ at pH 8.3), $2 \mathrm{mM} \mathrm{MgCl}_{2}, 200 \mu \mathrm{M}$ dNTPs, 2.5 units of AmpliTaq DNA polymerase (Applied Biosystems), $0.1 \mu \mathrm{M}$ of both forward and reverse primers, and varying amounts of template DNA. The reactions were started with a 5-min incubation at $72^{\circ} \mathrm{C}$ and then cycled at $94^{\circ} \mathrm{C}$ for $30 \mathrm{sec}$, $60^{\circ} \mathrm{C}$ for $30 \mathrm{sec}$, and $72^{\circ} \mathrm{C}$ for $30 \mathrm{sec}$ for 30 rounds of amplification. The reaction was completed with a final 7 -min extension step performed at $72^{\circ} \mathrm{C}$.

\section{ELCL Detection of PCR Products}

Following PCR, $1 \mu \mathrm{l}$ of product was combined with $30 \mu \mathrm{g}$ of streptavidin (SA) Dynabeads (Applied Biosystems), in a final volume of $50 \mu \mathrm{l}$ with PCR buffer II, and incubated for $15 \mathrm{~min}$ at room temperature with vortexing. SA-captured PCR products were then analyzed via the QPCR System 5000 following the addition of QPCR assay buffer. For analysis of coamplified target and competitor sequences, $1 \mu \mathrm{l}$ of PCR product was subjected to $\mathrm{XbaI}$ digestion for $1 \mathrm{hr}$ in a total volume of $30 \mu \mathrm{l}$ and incubated with SA Dynabeads as described. In addition, a mock digestion was performed in parallel to assess total sample luminosity.

\section{RESULTS AND DISCUSSION}

The utilization of ECL for the detection of PCR products using the QPCR system 5000 (Applied Biosystems) has been described recently. ${ }^{(6)}$ In brief, PCR products generated using biotin- and TBR-labeled primers possess the dual capacity of being captured by SA-labeled magnetic beads and producing light following electrical stimulation. The basis of the competitive PCR assay described here is outlined in Figure 2. In a series of parallel PCR reactions, a constant amount of CDNA is coamplified in the presence of varying amounts of competitor. During amplification, the DNA templates compete for a finite amount of derivatized primers, usually present in the reaction at a concentration $<0.5 \mu \mathrm{M}$. As the target and competitor sequences compete identically for a limited pool of primers and are presumably coamplified with equal efficiency, one is able to determine the starting target cDNA concentration by extrapolating from a curve generated by plotting the target to competitor ratio at varying competitor template concentrations. The amount of

FICURE 2 General scheme of the competitive PCR assay described in Results and Discussion. The abbreviations used are as follows: (B) Biotin; (TBR) Tris (2,2'-bipyridine) ruthenium (II) chelate; (SA) streptavidin. 

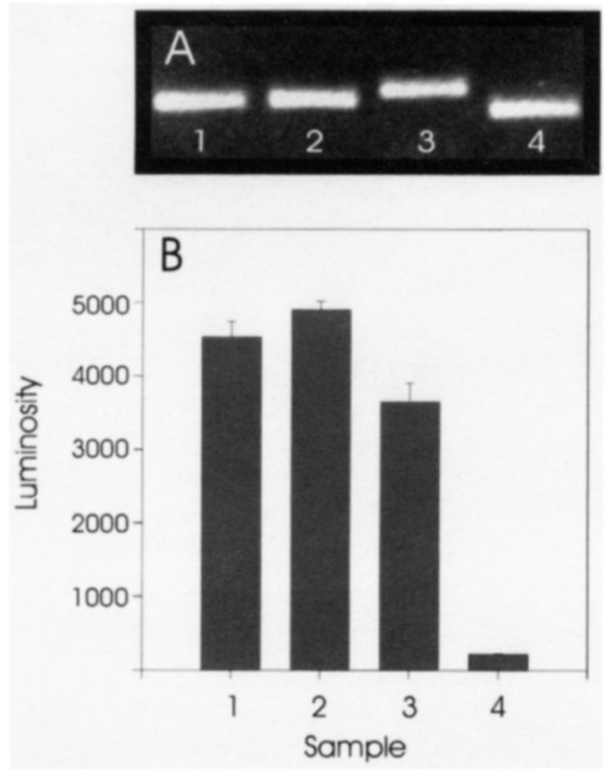

FIGURE 3 Effect of $X b a$ I digestion on the luminosity of the IL-1 $\beta$ target and competitor molecules. Target and competitor molecules were generated as described in Materials and methods and subjected to a mock or XbaI digestion as described in Materials and methods. (Lanes 1,3) Mock-digested target and competitor molecules; (lanes 2,4) XbaI-digested target and competitor molecules. $(A)$ DNA electrophoresis of $30 \mu \mathrm{l}$ of samples (lanes $1-4$ ) on a $2 \%$ agarose gel. The predicted and actual size of the DNA bands are $272 \mathrm{bp}$ for the target and 282 and 253 bp for the mock- and $X b a I$-digested competitor, respectively. (B) QPCR analysis of $1 \mu \mathrm{l}$ of samples (lanes 1-4). The analysis was performed in triplicate for each sample. The bars represent the standard error of the mean.

competitor and target DNA template are equivalent when their respective products are present in equal amounts, that is, when the target to competitor ratio is equal to 1 .

Because the use of derivatized primers confers the property of ECL to both the competitor and target PCR products, determination of the relative contribution of each to the total luminosity is an essential requirement of the assay. This is achieved by way of a unique restriction site built into the competitor DNA sequence and not found in the endogenous target sequence. As shown in Figure 3 , restriction enzyme digestion of the competitor product dissociates the property of ELCL, conferred on the product by way of the TBR moiety, from the biotin group, which is necessary for capture. As a result, digestion of a mixture of competitor and target molecules will produce a luminosity measurement contributed primarily by the target alone (see Fig. 3). The target product is unaffected by $X b a I$ (a site contained solely in the competitor) digestion (Fig. 3A,B, lanes 2), whereas the competitor product is cleaved, thereby significantly reducing the luminosity (Fig. 3A,B, lanes 4). Results of mock digestions are indicated in lanes 1 and 3 for target and competitor respectively. Although the digestion of the competitor was only $\sim 94 \%$ complete, as indicated by the luminosity (Fig. 3, lanes 4), our experience has shown that the outcome of competitive PCR experiments is unaffected providing that the comparisons made are relative and are made within the same experiment.

Application of the competitive PCR assay (described above) to the measurement of interleukin-1 $\beta$ (IL-1 $\beta$ ) mRNA transcripts in rat cerebral cortex and spleen stimulated by intraperitoneal injections of kainic acid and lipopolysacharride (LPS), respectively, is shown in Figure 4. Comparisons of vehicle [phosphate-buffered saline (PBS) $(0.9 \% \mathrm{NaCl}$, $\left.0.1 \mathrm{M} \mathrm{NaH}_{2} \mathrm{PO}_{4}\right)$ ] versus treatment rats were made at a target-to-competitor ratio of 1 and revealed 50- and 8.5-fold changes of IL-1 $\beta$ mRNA transcripts in cortex and spleen, respectively. These observations are consistent with the known reported effects of these stimulants and serve to validate the assay. ${ }^{(7,8)}$

In summary, we report here on a competitive PCR method employing ELCL detection, which is useful for the evaluation of changes of specific mRNA transcripts in biological systems. This assay accounts for differences in amplification efficiency between PCR reactions by normalizing the amount of endogenous target product to the amount of coamplified competitor product. Because a unique restriction enzyme site is contained within the competitor template, ELCL quantitation of both coamplified target and competitor molecules becomes possible. Therefore, the nonradioactive quantitation of very low concentrations of PCR product becomes possible, as this method of detection offers an extremely high degree of sensitivity, reportedly down to the attomole level. ${ }^{(6)}$ Although the efficiency of the conversion of mRNA to cDNA was not accounted for in this assay, one could easily incorporate the use of a mutated RNA competitor into the RT reaction. ${ }^{(9)}$ As a result, the assay would be normalized for differences in efficiences in both the RT and PCR steps of the protocol, as the target and competitor molecules are core-
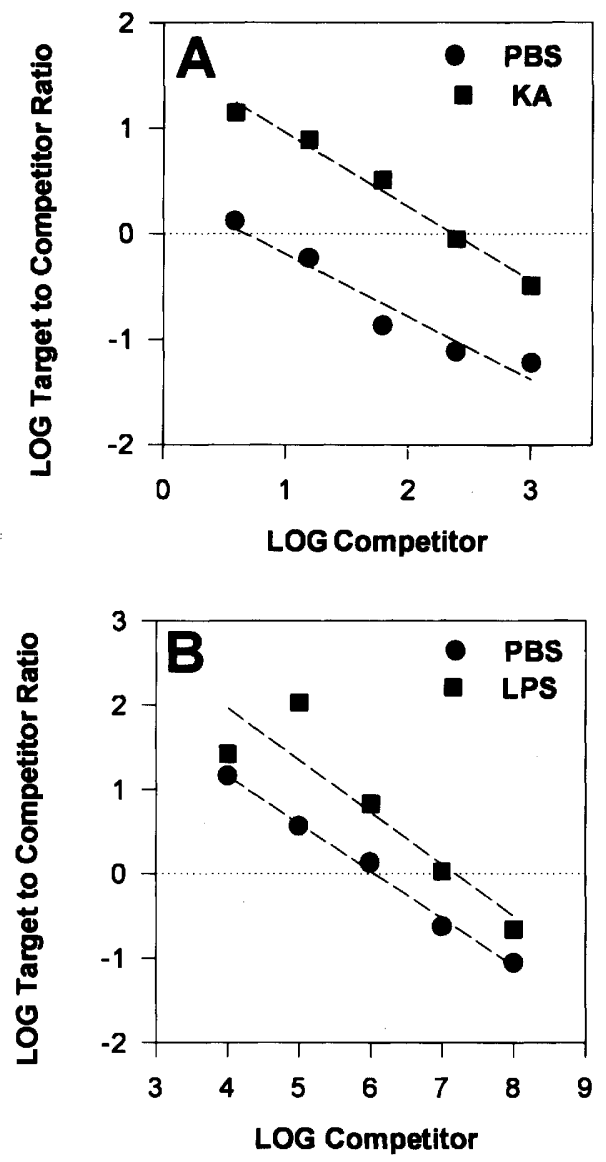

FICURE 4 Competitive PCR analysis of changes in IL-1 $\beta$ mRNA levels in rat cortex and spleen following stimulation with kainic acid and LPS, respectively. (A) Rats were injected intraperitoneally with a PBS solution containing kainic acid $(10 \mathrm{mg} / \mathrm{kg}$ body weight) and sacrificed $2 \mathrm{hr}$ later. The cortex was rapidly removed and processed as described. A constant amount of cDNA was subsequently coamplified in the presence of a varying amount of competitor. The absolute amount of competitor was not determined, as only relative fold changes between control and stimulated rats was desired. The amount of target and competitor was determined as described in ELCL Detection of PCR Products. The relative fold change in IL- $1 \beta$ mRNA transcripts between control and stimulated cortical samples was normalized for total RNA content and was determined at a target-tocompetitor ratio equal to 1 . (B) Rats were injected intraperitoneally with a suspension of PBS containing LPS $(250 \mu \mathrm{g} / \mathrm{kg}$ body weight) and sacrificed $2 \mathrm{hr}$ later. Tissue samples were processed as described in $A$. 
verse transcribed as well as coamplified together. The general technique described here could also be employed with other systems presently used for the detection of PCR products. For example, the basic strategy would be useful for the discernment of target and competitor molecules in any one of a number of available systems that employ a haptenlabeled primer followed by conjugated antibody binding and colorimetric detection.

\section{REFERENCES}

1. Saiki, R., S. Scharf, F. Faloona, K. Mullis, G. Horn, H. Erlich, and N. Arnheim. 1985. Enzymatic amplification of beta-globin genomic sequences and restriction site analysis for diagnosis of sickle cell anemia. Science 230: 1350-1354.

2. Chelly, J., J.C. Kaplan, P. Maire, S. Gautron, and A. Kahn. 1988. Transcription of the dystrophin gene in human muscle and non-muscle tissues. Nature 333: 858-860.

3. Gilliland, G., S. Perrin, K. Blanchard, and F.F. Bunn. 1990. Analysis of cytokine mRNA and DNA: Detection and quantitation by competitive polymerase chain reaction. Proc. Natl. Acad. Sci. 87: 27252729.

4. Diviacco, S., P. Norio, L. Zentilin, S. Menzo, M. Clementi, G. Biamonti, S. Riva, A. Falaschi, and M. Giacca. 1992. A novel procedure for quantitative polymerase chain reaction by coamplification of competitive templates. Gene 122: 3013-3020.

5. Jin, C., M. Mata, and D.J. Fink. 1994. Rapid construction of deleted DNA fragments for use as internal standards in competitive PCR. PCR Methods Applic. 3: 252-255.

6. DiCesare, J., B. Grossman, E. Katz, E. Picozza, R. Ragusa, and T. Woudenberg. 1993. A high-sensitivity electrochemiluminescence-based detection system for automated PCR product quantitation. BioTechniques 15: 152-157.

7. Minami, M., Y. Kuraishi, T. Yamaguchi, S. Nakai, Y. Hirai, and M. Satoh. 1990. Convulsants induce interleukin- $1 \beta$ messenger RNA in rat brain. Biochem. Biophys. Res. Commun. 171: 832-837.

8. Takao, T., S.G. Culp, R.C. Newton, and E.B. De Souza. 1992. Type 1 interleukin-1 receptors in the mouse brain-endocrineimmune axis labeled with $\left[{ }^{125}\right]$ recombinant human interleukin-1 receptor antagonist. J. Immunol. 41: 51-60.

9. Becker-Andre, M. and K. Hahlbrock. 1994. Absolute mRNA quantitation using the polymerase chain reaction (PCR). A novel approach by PCR aided transcript titra- tion assay (PATTY). Nucleic Acids Res. 17: 9437-9445.

Received February 13, 1995; accepted in revised form April 10, 1995. 


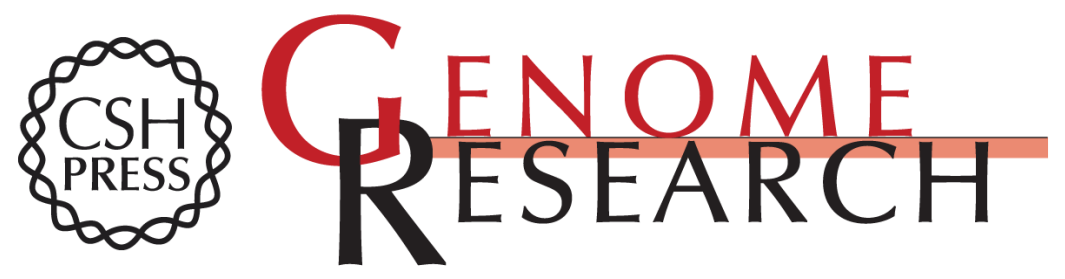

\section{Quantitative analysis of specific mRNA transcripts using a competitive PCR assay with electrochemiluminescent detection.}

J A Heroux and A M Szczepanik

Genome Res. 1995 4: 327-330

References This article cites 9 articles, 2 of which can be accessed free at: http://genome.cshlp.org/content/4/6/327.full.html\#ref-list-1

License

Email Alerting Receive free email alerts when new articles cite this article - sign up in the box at the Service top right corner of the article or click here.

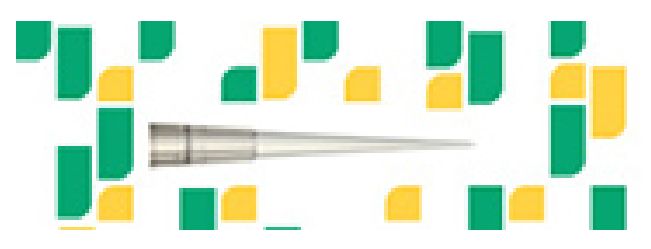

Focused on your science.

To subscribe to Genome Research go to:

https://genome.cshlp.org/subscriptions 